\title{
Ty-3, a begomovirus resistance locus near the Tomato yellow leaf curl virus resistance locus Ty-1 on chromosome 6 of tomato
}

\author{
Yuanfu Ji · David J. Schuster · Jay W. Scott
}

Published online: 15 May 2007

(C) Springer Science+Business Media B.V. 2007

\section{Erratum to: Mol Breeding \\ DOI 10.1007/s11032-007-9089-7}

The column headings of the markers in Table 5 of the original were incorrect. The correct headings are TG231 (left column) and PG3 (right column).

The online version of the original article can be found at http:// dx.doi.org/10.1007/s11032-007-9089-7

Y. Ji · D. J. Schuster · J. W. Scott ( $₫)$

Gulf Coast Research and Education Center, University of Florida, 14625 CR 672, Wimauma, FL 33598, USA

e-mail: jwsc@ufl.edu 